\title{
PERAN KOMUNIKASI PENYULUHAN DALAM PENERAPAN TEKNOLOGI USAHATANI DI KECAMATAN LANGOWAN BARAT
}

\author{
Clara F. Mongisidi \\ Lyndon R. J. Pangemanan \\ Rine Kaunang
}

\begin{abstract}
ABSRACT
This study aims to determine the role of communication extension counselor and how far farmers can understand the purpose and purpose of counseling. This research was conducted by using primary data obtained from direct interview with Field Extension Officer and Farmer Group using the prepared kusioner. Secondary data obtained from BPS Manado City and BP3K Office. The result of the research shows that the communication done by PPL has used good communication technique so that the farmer group following the counseling can receive and understand the intent and purpose of the material which have been submitted by each PPL.
\end{abstract}

Keywords: Role, Communication, Counseling, Application, Technology, Farming, District of West Langowan

\begin{abstract}
ABSTRAK
Penelitian ini bertujuan untuk mengetahui peran komunikasi penyuluh saat melakukan penyuluhan dan sejauh mana petani dapat memahami maksud dan tujuan penyuluhan. Penelitian ini dilaksanakan dengan mengunakan data primer diperoleh dari wawancara langsung dengan Petugas Penyuluh Lapangan dan Kelompok Tani dengan menggunakan kusioner yang telah disiapkan. Data sekunder yang diperoleh dari BPS Kota Manado dan Kantor BP3K. Hasil penelitian menunjukkan bahwa komunikasi yang dilakukan PPL telah memakai teknik komunikasi yang baik sehingga kelompok tani yang mengikuti penyuluhan dapat menerima dan memahami maksud dan tujuan dari materi yang telah disampaikan oleh masing-masing PPL.

Kata kunci: Peran, Komunikasi, Penyuluhan, Penerapan, Teknologi, Usahatani, Kecamatan Langowan Barat
\end{abstract}




\section{PENDAHULUAN}

\section{Latar Belakang}

Penyuluhan pertanian di Indonesia telah mempunyai sejarah yang cukup panjang, yang dimulai sejak abad 20 di masa penjajahan. Penyuluhan bermula dari adanya kebutuhan untuk meningkatkan hasil pertanian, baik untuk kepentingan penjajah maupun untuk mencukupi kebutuhan pribumi. Penyuluhan dilandasi pula oleh kenyataan adanya kesenjangan yang cukup jauh antara praktek-praktek yang dilakukan para petani di satu pihak dan adanya teknologiteknologi yang lebih maju dilain pihak. Penyuluhan pertanian didefinisikan sebagai suatu sistem pendidikan di luar sekolah untuk keluargakeluarga tani di pedesaan, di mana mereka belajar sambil berbuat untuk menjadi mau, tahu dan bisa menyelesaikan sendiri masalah-masalah yang dihadapinya secara baik, menguntungkan dan memuaskan (Wiriaatmadja, 1986). Kegiatan penyuluhan pertanian adalah suatu kegiatan penyampaian informasi kepada orang lain, dengan harapan orang tersebut dapat berubah perilakunya dengan mau melaksanakan informasi yang disampaikan.

Seseorang berubah perilakunya dapat disebabkan setelah berinteraksi dengan orang lain. Bila kita ingin berinteraksi dengan orang lain, maka komunikasi amat diperlukan. Sehingga informasi apa yang ingin kita sampaikan dapat diterima oleh mereka. Berbicara penyuluhan, penyuluhan adalah proses pendidikan nonformal, yang intinya ingin merubah perilaku dari sasaran penyuluhan itu. Perubahan perilaku dapat terjadi apabila terjadi interaksi penyuluh yang akan menyampaikan informasi baru dengan sasaran dengan melakukan komunikasi dengan baik. Pertanyaannya, apakah komunikasi sudah berjalan dengan baik. Penyuluh pertanian dapat dan harus menggunakan teknik-teknik komunikasi yang paling efektif agar sasaran mau menerapkan pengetahuan barunya itu. Melalui komunikasi yang efektif dapat menunjang keberhasilan penyuluhan pertanian. Dalam kegiatan penyuluhan pertanian, komunikasi menjadi sebuah faktor penting yang dapat menunjang tercapainya tujuan-tujuan penyuluhan. Setiap petani di suatu daerah pertanian memiliki karakteristik yang berbeda-beda, oleh karenanya penyajian komunikasi punperlu disesuaikan dengan daerah masing-masing petani. Para petani yang masih berada di daerah pedesaan yang terisolir tentunya lebih efektif jika diberikan penyuluhan dengan metode dialog dua arah serta pendekatan interpersonal. Terdapat korelasi positif yang nyata antara kompetensi komunikasi yang dimiliki oleh penyuluh terhadap perilaku petani dalam mengelola sumber daya yang dimiliki. Selain faktor keterisoliran dan kompetensi komunikasi, strategi komunikasi pun berpengaruh terhadap efektifitas komunikasi. Penyelenggara penyuluhan pertanian ditingkat lapangan harus sesuai dengan kebutuhan pelaku utama dan pelaku usaha melalui program pembangunan pertanian secara luas yang diturunkan oleh dinas pertanian sehingga semua dapat dilaksanakan dengan baik sesuai tujuan yang ingin dicapai. Maka diperlukan sebuah kajian mendalam untuk mengetahui bagaimana seharusnya penyajian komunikasi pertanian yang efektif dalam kegiatan penyuluhan terhadap ragam petani yang tersebar di berbagai daerah agar para petani dapat tercerahkan dan berkembang cara berpikirnya dan mengetahui sampai sejauh mana keberhasilan Petugas Penyuluh Lapangandi Kecamatan Langowan Barat. Kecamatan Langowan Barat terdapat 16 desadan dibimbing oleh 4 orang Petugas Penyuluh Lapangan (PPL), 1 orang PPL bertugas di empat desa, setiap desa memiliki kelompok tani.

\section{Rumusan Masalah}

Berdasarkan latar belakang yang telah dikemukakan maka yang menjadi permasalahan dalam penelitian ini yaitu:

1. Apakah PPL (komunikator) sudah menjalankan perannya sebagai penyuluh dengan baik

2. Apakah Penyuluhan yang dilakukan PPL (komunikator) dapat diterima oleh petani (komunikan)

\section{Tujuan Penelitian}

Penelitian ini bertujuan untuk mengetahui:

1. Peran Komunikasi PPL (komunikator) saat melakukan Penyuluhan

2. Sejauh mana petani (komunikan) dapat memahami maksud dan tujuan dari apa yang sudah disuluhkan 


\section{Manfaat Penelitian}

Untuk mengetahui peran komunikasi PPL (komunikator) kepada petani (komunikan) lewat materi dan gagasan baru yang disuluhkan di Kecamatan Langowan Barat.

\section{METODE PENELITIAN}

\section{Lokasi dan Waktu Penelitian}

Penelitian ini dilakukan di Kecamatan Langowan Barat.Penelitian ini dilakukan selama 2 bulan yaitu bulan Oktober dan November 2016.

\section{Pengambilan Sampel}

Metode pengambilan data pada penelitian ini dilakukan dengan metode survey. Melalui wawancara kepada Penyuluh dan kuisioner yang diberikan Kelompok Tani. Pengambilan informasi meliputi seluruh Petugas Penyuluh Lapangan (komunikator) serta anggota kelompok tani (komunikan) di Kecamatan Langowan Barat.

\section{Metode Pengumpulan Data}

Data yang digunakan dalam penelitian ini adalah pengumpulan data primer dan data sekunder. Data primer adalah data yang dikumpulkan melalui survey dan wawancara langsung dengan ketua BP3K dan Petugas Penyuluh Lapangan (PPL) dan anggota kelompok tani binaan dari PPL di Kecamatan Langowan Barat. Sedangkan data sekunder adalah data yang didapat dari instansi yang terkait dalam hal ini Kantor BP3K di Kecamatan Langowan Barat dan Kantor Badan Pusat Statistika (BPS) Propinsi Sulawesi Utara.

\section{Konsep dan Pengukuran Variabel}

Variabel yang diukur dalam penelitian ini adalah :
a) Data Umum Tentang Responden Kelompok Tani (Komunikan)
1. Nama
2. Alamat
3. Umur/usia responden (Tahun)
4. Tingkat pendidikan terakhir (SMA, SPMA, D3 dan Sarjana)

Kuisioner untuk Kelompok Tani (Komunikan).

\section{b) Tingkat penyerapan/penerapan}

1. Penerapan penyuluh, apakah menerapkan teknik berkomunikasi :

a. Cara memilih pokok persoalan yang akan disuluhkan

b. Berbicara diiringi bantuan gerak-gerik

c. Alat yang dipakai saat penyuluhan

d. Menyesuaikan situasi

e. Menghargai dan menghormati lawan bicara dengan baik

f. Menganggapi setiap reaksi, saran, usul dari lawan bicara

2. Penyerapan petani:

a. Pengetahuan Petani (kognitif)

b. Perasaan Petani setelah mengikuti penyuluhan (afektif)

c. Tindakan Petani (motorik)

\section{Metode Analisis Data}

Metode analisis yang digunakan dalam penelitian ini adalah metode analisis deskriptif, dimana metode analisis ini mendeskripsikan setiap data yang diambil. Pengamatan yang diarahkan untuk memperoleh fakta-fakta yang di analisis menggunakan metode analisisdeskriptif, data hasil wawancara dari Petugas Penyuluh Lapangan dan Kelompok Tani diolah dan dibuat tabulasi, kemudian hasilnya di interprestasikan sesuai dengan tujuan yang ingin dicapai. Untuk mengetahui peran komunikasi dari penyuluhan di gunakan Skala Likert. Analisis data dalam penelitian ini adalah deskriptif dengan menggunakan daftar tabel dan angka. Untuk mengukur sikap akan disusun 9 pernyataan dengan total responden 36. Adapun metode penilaian yang nantinya akan diteliti dengan kriteria penilaian:

- Range skor 5, berkategori baik sekali. Petani memahami dengan benar serta melakukan setiap materi yang disuluhkan.

- Range skor 4, berkategori baik. Petani dapat mengerti tetapi dalam penerapannya tidak sepenuhnya melakukan sesuai dengan materi yang diterima.

- Range skor 3, berkategori sedang. Petani dapat mengerti materi penyuluhan tetapi tidak melakukan.

- Range skor 2, berkategori buruk. Petani tidak begitu memahami sehingga tidak dapat melakukan. 
- Range skor 1, berkategori sangat buruk. Petani tidak dapat mengerti dan memahami sehingga tidak dapat melakukannya.

Dengan cara perhitungan skor masing-

masing pernyataan:

Jumlah Skor Tiap Kriterium = Capaian Skor $\mathrm{x}$

Jumlah Responden:

$\mathrm{S}_{5}=5 \times 9=45$

$\mathrm{S}_{4}=4 \times 9=36$

$\mathrm{S}_{3}=3 \times 9=27$

$\mathrm{S}_{2}=2 \times 9=18$

$\mathrm{S}_{1}=1 \times 9=9$

Jumlah skor ideal untuk siap pernyataan (Skor

Tertinggi) $=45$

Jumlah skor terendah $=9$

Dengan Interpretasi nilai:

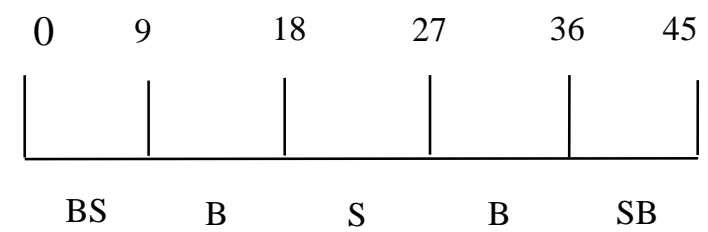

Cara perhitungan skor keseluruhan untuk mengetahui sikap :

Jumlah Skor Seluruh Kriterium = Capaian

Jumlah Skor x Jumlah Responden x Instrument pernyataan

Untuk :

$\mathrm{S}_{5}=5 \times 9 \times 9=405$

$\mathrm{S}_{4}=4 \times 9 \times 9=324$

$\mathrm{S}_{3}=3 \times 9 \times 9=243$

$\mathrm{S}_{2}=2 \times 9 \times 9=162$

$\mathrm{S}_{1}=1 \times 9 \times 9=81$

Jumlah skor ideal untuk keseluruhan pernyataan $=405$ (Tertinggi)

Jumlah skor terendah $=81$ (Rendah)

Dengan Interpretasi nilai:

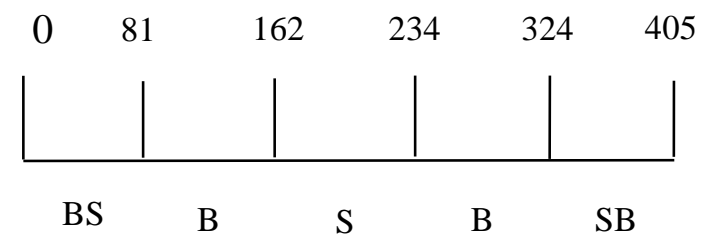

Analisis data yang digunakan merupakan analisis deskriptif yang analisis dengan menggunakan skala pengukuran sikap Likert Scale dimana menurut Ridwan (2010) dalam buku Rumus dan Data dalam Analisis Statistika, adalah sebagai berikut:

Total skor $=\frac{\text { JumlahSkorHasilPengumpulanData }}{\text { JumlahSkorIdeal }(\text { Tertinggi })} \times 100 \%$

Dengan Interpretasi nilai:

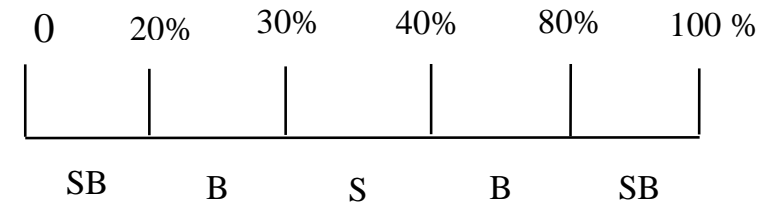

Angka 0\%-20\% = Sangat Buruk

Angka $21 \%-40 \%=$ Buruk

Angka $41 \%-60 \%=$ Sedang

Angka $61 \%-80 \%=$ Baik

Angka $81 \%-100 \%=$ Baik Sekali

\section{HASIL DAN PEMBAHASAN}

\section{Gambaran Umum Wilayah Penelitian}

Langowan Barat adalah sebuah Kecamatan di Kabupaten Minahasa, Sulawesi Utara, Indonesia. Kecamatan ini merupakan hasil pemekaran dari Kecamatan Langowan, yang kini menjadi tiga Kecamatan, yakni Kecamatan Langowan Barat, Kecamatan Langowan Timur dan Kecamatan Langowan Selatan. Kecamatan Langowan Barat dibagi menjadi 16 Desa, yakni Desa Tounelet, Desa Koyawas, Desa Walewangko, Desa Noongan, Desa Raringis, Desa Ampreng, Desa Paslaten, Desa Kopiwangker, Desa Lowian, Desa Tumaratas, Desa Tumaratas II, Desa Noongan II, Desa Noongan III, Desa Raranon, Desa Raringis Selatan, dan Desa Raringis Utara. Kecamatan Langowan Barat memiliki batas-batas sebagai berikut:

- Sebelah Utara : Kecamatan Tompaso dan Langowan Utara

- Sebelah Timur : Kecamatan Langowan Timur dan Langowan Utara

- Sebelah Selatan : Kabupaten Minahasa Tenggara

- Sebelah Barat : Kabupaten Minahasa Tenggara

\section{Karakteristik Responden}

Karakteristik responden dalam penelitian ini diperoleh berdasarkan hasil survey dan wawancara langsung dengan PPL dan Kelompok Tani yang ada di Kecamatan 
Langowan Barat. Karakterikstik umum terdiri dari usia, tingkat pendidikan dan lamanya menjadi anggota Kelompok Tani.

\section{Tingkat Umur}

Tingkat usia menggambarkan kemampuan dan pengalaman dari Petani. Semakin tua maka kemampuan fisik akan semakin menurun, sebaliknya pengalaman dan ilmu yang didapat semakin banyak.

\begin{tabular}{cccc}
\multicolumn{5}{c}{ Tabel 1. Umur Responden Petani sebagai } \\
\multicolumn{4}{c}{ Komunikan } \\
\hline No & Umur & Jumlah & Presentase \\
& (tahun) & Responden & $(\%)$ \\
\hline 1 & $41-50$ & 14 & 38,8 \\
2 & $51-60$ & 16 & 44,4 \\
3 & $61-70$ & 6 & 16,6 \\
\hline & Jumlah & 36 & 100 \\
\hline
\end{tabular}

Sumber Data Primer, November 2016

Tabel 1 menunjukkan bahwa jumlah responden interval 51 - 60 tahun 44,4 persen, dan selanjutnya pada interval $41-50$ tahun 38,8 persen, dan yang paling sedikit responden yang berada pada interval umur $61-70$ tahun 16,6 persen.

\section{Tingkat Pendidikan Responden Petani}

Faktor pendidikan berpengaruh pada tingkat penyerapan dan pengetahuan yang diterima oleh responden. Semakin tinggi tingkat pendidikan berpengaruh baik untuk penyerapan materi penyuluhan.

Tabel 2. Jumlah Responden menurut tingkat pendidikan Petani

\begin{tabular}{cccc}
\multicolumn{4}{c}{ pendidikan Petani } \\
\hline $\mathrm{N}$ & Tingkat & $\begin{array}{c}\text { Jumlah } \\
\text { Responden }\end{array}$ & Presentase (\%) \\
\hline 1 & pendidikan & 14 & 38,8 \\
2 & SD & 13 & 36,1 \\
3 & SMA & 9 & 25 \\
\hline & Jumlah & 36 & 100 \\
\hline
\end{tabular}

Sumber Data Primer, November 2016

Tabel 2 menunjukkan tingkat pendidikan yang dimiliki responden. Tingkat pendidikan responden yang paling banyak SD sebanyak 14 responden 38,8 persen, sedangkan tingkat SMP 13 responden 36,1 persen dan tingkat SMA 9 responden 25 persen.

\section{Lama bekerja sebagai Petani}

Lama bekerja sebagai petani dapat memberikan banyak pengetahuan dalam menjalankan pekerjaan bertani.

Tabel 3. Responden menurut lama bekerja sebagai Petani

\begin{tabular}{cccc}
\hline No & $\begin{array}{c}\text { Lama } \\
\text { (tahun) }\end{array}$ & $\begin{array}{c}\text { Jumlah } \\
\text { (orang) }\end{array}$ & Presentase (\%) \\
\hline 1 & $<10$ & 24 & 66,6 \\
2 & $>11$ & 12 & 33,3 \\
\hline & Jumlah & 36 & 100 \\
\hline
\end{tabular}

Sumber Data Primer, November 2016

Tabel 3 menunjukkan lamanya responden bekerja sebagai petani yaitu rata-rata 10 tahun, yang paling rendah yakni 5 tahun dan paling lama bekerja sebagai petani yaitu 30 tahun.

\section{Pembahasan}

Berikut ini dijelaskan bagaimana peran komunikasi penyuluhan dalam penerapan teknologi usaha tani di Kecamatan Langowan Barat. Berdasarkan hasil wawancara dengan PPL 1, dilihat dari tabel dibawah ini.

Tabel 4. Penyerapan Petani (Hasil wawancara dengan PPL 1)

\begin{tabular}{lcc}
\hline No & $\begin{array}{c}\text { Penyerapan } \\
\text { Kelompok Tani }\end{array}$ & Hasil wawancara \\
\hline 1 & $\begin{array}{c}\text { Perasaan petani } \\
\text { (afektif) }\end{array}$ & Sangat Baik \\
2 & $\begin{array}{c}\text { Pengetahuan petani } \\
\text { (kognitif) } \\
\text { Tindakan petani } \\
\text { (motorik) }\end{array}$ & Sangat Baik \\
& Sangat Baik \\
\hline
\end{tabular}

Sumber data primer, November 2016

Tabel 4 menunjukan bahwa PPL 1 menerapkan teknik komunikasi dengan baik saat penyuluhan sehingga kelompok tani tertarik dan dapat menerima setiap materi yang disuluhkan serta melakukan. Alat yang dipakai saat penyuluhan hanya memakai alat seadanya seperti megafon, karton dan alat tulis menulis. Megafon hanya dipakai saat diadakan penyuluhan massal yang dilakukan dikantor BP3K Kecamatan Langowan Barat. Tabel 5 menunjukan bahwa 100 persen responden (9 orang) setuju dengan cara pemilihan pokok bahasan dari PPL 1. Total skor 
yang diperoleh dari indikator nomor 1 ini adalah sebesar 45. Angka indeks sikap dari pernyataan nomor 1 yaitu : $45 / 45 \times 100 \%=100 \%$. sehingga interpretasi nilainya tergolong baik sekali. Tabel 6 menunjukan bahwa 77,7 persen responden (7 orang) menjawab baik sekali dengan pernyataan berbicara diiringi bantuan gerak-gerik. Sedangkan 22,2 persen responden ( 2 orang) menjawab baik. Total skor yang diperoleh dari indikator nomor 2 ini adalah 43. Angka indeks mengenai pernyataan nomor 2 yaitu : $43 / 45 \times 100 \%=95,5 \%$ sehingga interpretasinya tergolong baik sekali. Tabel 7 menunjukan bahwa 88,8 persen respondern ( 8 orang) menjawab baik dengan pernyataan alat yang dipakai PPL 1 saat penyuluhan. Sedangkan 11,1 persen responden (1 orang) menjawab baik sekali. Total skor yang diperoleh dari indikator ini adalah 37. Angka indeks mengenai pernyataan nomor 3 yaitu : 37 / $45 \times 100 \%=82,2 \%$ sehingga interpretasinya tergolong baik sekali. Tabel 8 menunjukan bahwa 66,6 persen responden (6 orang) menjawab baik sekali dengan pernyataan nomor 4. Sedangkan 33,3 persen responden (3 orang) menjawab baik. Total skor yang diperoleh dari indikator ini adalah 42. Angka indeks mengenai pernyataan nomor 4 yaitu : 42 / $45 \mathrm{x}$ $100 \%=93,3 \%$ sehingga interpretasinya tergolong baik sekali.

Tabel 5. Cara pemilihan pokok bahasan dari PPL 1 (hasil wawancara dengan binaan PPL 1)

\begin{tabular}{cccccc}
\hline Alternatif Jawaban & Alternatif Skor & Jumlah Responden & Persentase Responden & Total Skor (\%) \\
\hline Baik Sekali & 5 & 9 & 100 & 45 \\
Baik & 4 & - & - & - \\
Sedang & 3 & - & - & - \\
Buruk & 2 & - & - & - \\
Sangat Buruk & 1 & - & - & - \\
\hline Total & & 9 & 100 & 45
\end{tabular}

Sumber: Diolah dari data primer, 2016

Tabel 6. Berbicara diiringi bantuan gerak-gerik (hasil wawancara dengan binaan PPL 1)

\begin{tabular}{ccccc}
\hline Alternatif Jawaban & Alternatif Skor & Jumlah Responden & Persentase Responden & Total Skor $(\%)$ \\
\hline Baik Sekali & 5 & 7 & 77,7 & 35 \\
Baik & 4 & 2 & 22,2 & 8 \\
Sedang & 3 & - & - & - \\
Buruk & 2 & - & - & - \\
Sangat Buruk & 1 & - & - & - \\
\hline Total & & 9 & 100 & 43 \\
\hline
\end{tabular}

Sumber : Diolah dari data primer, 2016

Tabel 7. Alat yang dipakai saat penyuluhan (hasil wawancara dengan binaan PPL 1)

\begin{tabular}{ccccc}
\hline Alternatif Jawaban & Alternatif Skor & Jumlah Responden & Persentase Responden & Total Skor (\%) \\
\hline Baik Sekali & 5 & 1 & 11,1 & 5 \\
Baik & 4 & 8 & 88,8 & 32 \\
Sedang & 3 & - & - & - \\
Buruk & 2 & - & - & - \\
Sangat Buruk & 1 & - & 100 & - \\
\hline Total & & 9 &
\end{tabular}

Sumber : Diolah dari data primer, 2016

Tabel 8. Menyesuaikan situasi (hasil wawancara dengan binaan PPL 1)

\begin{tabular}{ccccc}
\hline Alternatif Jawaban & Alternatif Skor & Jumlah Responden & Persentase Responden & Total Skor (\%) \\
\hline Baik Sekali & 5 & 6 & 66,6 & 30 \\
Baik & 4 & 3 & 33,3 & 12 \\
Sedang & 3 & - & - & - \\
Buruk & 2 & - & - & - \\
Sangat Buruk & 1 & - & - & - \\
\hline Total & & 9 & 100 & 42 \\
\hline
\end{tabular}

Sumber : Diolah dari data primer, 2016 
Tabel 9 menunjukan bahwa 88,8 persen responden ( 8 orang) menjawab baik sekali dengan pernyataan nomor 5 . Sedangkan 11,1 persen responden (1 orang) menjawab baik. Total skor yang diperoleh dari indikator adalah 44. Angka indeks dari pernyataan nomor 5 yaitu $44 / 45 \times 100 \%=97,7 \%$ sehingga interpretasinya tergolong baik sekali. Tabel 10 menunjukan bahwa 100 persen responden ( 9 orang) menjawab baik sekali dengan cara PPL 1 menganggapi setiap reaksi, saran, dan usul dari lawan bicara. Total skor yang diperoleh dari indikator adalah 45. Angka indeks dari pernyataan nomor 6 yaitu : $45 / 45 \times 100 \%=$ $100 \%$ sehingga interpretasinya tergolong baik sekali. Tabel 11 menunjukan bahwa 88,8 persen responden ( 8 orang) menjawab baik sekali dengan pengetahuan yang didapat oleh komunikan sedudah mengikuti penyuluhan dari PPL 1. Sedangkan 11,1 persen responden (1 orang) menjawab baik. Total skor y6ang diperoleh dari indikator ini adalah 44. Angka indeks dari pernyataan nomor 7 yaitu : 44 / $45 \mathrm{x}$ $100 \%=97,7 \%$ sehingga interpretasinya tergolong baik sekali.

Tabel 9. Menghargai dan menghormati lawan bicara dengan baik (hasil wawancara dengan binaan PPL 1)

\begin{tabular}{ccccc}
\hline $\begin{array}{c}\text { Alternatif } \\
\text { Jawaban }\end{array}$ & Alternatif Skor & Jumlah Responden & Persentase Responden & Total Skor (\%) \\
\hline Baik Sekali & 5 & 8 & 88,8 & 40 \\
Baik & 4 & 1 & 11,1 & 4 \\
Sedang & 3 & - & - & - \\
Buruk & 2 & - & - & - \\
Sangat Buruk & 1 & - & - & - \\
\hline Total & & 9 & 100 & 44 \\
\hline
\end{tabular}

Sumber : Diolah dari data primer, 2016

Tabel 10. Menganggapi setiap reaksi, saran, dan usul dari lawan bicara (hasil wawancara dengan binaan PPL 1)

\begin{tabular}{ccccc}
\hline $\begin{array}{c}\text { Alternatif } \\
\text { Jawaban }\end{array}$ & Alternatif Skor & Jumlah Responden & Persentase Responden & Total Skor (\%) \\
\hline Baik Sekali & 5 & 9 & 100 & 45 \\
Baik & 4 & - & - & - \\
Sedang & 3 & - & - & - \\
Buruk & 2 & - & - & - \\
Sangat Buruk & 1 & - & - & - \\
\hline Total & & 9 & 100 & 45 \\
\hline
\end{tabular}

Sumber : Diolah dari data primer, 2016

Tabel 11. Pengetahuan yang didapat Petani setelah Penyuluhan dari PPL 1 (hasil wawancara dengan binaan PPL 1)

\begin{tabular}{ccccc}
\hline $\begin{array}{c}\text { Alternatif } \\
\text { Jawaban }\end{array}$ & Alternatif Skor & Jumlah Responden & Persentase Responden & Total Skor (\%) \\
\hline Baik Sekali & 5 & 8 & 88,8 & 40 \\
Baik & 4 & 1 & 11,1 & 4 \\
Sedang & 3 & - & - & - \\
Buruk & 2 & - & - & - \\
Sangat Buruk & 1 & - & - & - \\
\hline Total & & 9 & 100 & 44 \\
\hline
\end{tabular}

Sumber : Diolah dari data primer, 2016 
Tabel 12 menunjukan bahwa 55,5 persen responden (5 orang) mengatakan Baik sekali dengan pernyataan nomor 8 . Sedangkan 44,4 persen responden (4 orang) mengatakan baik. Total skor yang diperoleh dari indikator adalah 41. Angka indeks dari pernyataan nomor 8 ini yaitu : $41 / 45 \times 100 \%=91,1 \%$ sehingga angka interpretasinya tergolong baik sekali. Tabel 13 menunjukan bahwa 66,6 persen responden (6 orang) menjawab baik sekali. Sedangkan 33,3 persen responden (3 orang) menjawab baik. Total skor yang diperoleh dari indikator adalah 42. Angka indeks dari pernyataan ini adalah 42 / $45 \times 100 \%=93,3 \%$ sehingga angka interpretasinya tergolong baik sekali.

\section{Rekapitulasi Indeks dari Penyuluhan yang dilakukan PPL 1}

Rekapitulasi total skor, indeks sikap dan interpretasi dari penyuluhan yang dilakukan PPL 1. Tabel 14 menunjukkan bahwa terdapat 9 indikator yang diukur dalam penyuluhan yang dilakukan PPL 1 dimana indeks tertinggi pada pernyataan 1 dan 6 mendapat indeks 100 persen, sedangkan pernyataan 7 dan 5 mendapat indeks 97,7 persen, pernyataan 2 mendapat indeks 95,5 persen, pernyataan 4 dan 9 mendapat indeks 93,3 persen, pernyataan 8 mendapat indeks 91,1 dan pernyataan 3 mendapat indeks 82,2 persen. Dan semuanya mendapat interpretasi baik sekali. Hasil ini diperoleh dari wawancara langsung dengan anggota Kt. Imanuel (Desa Raringis) berjumlah 2 orang, Kt. Kelelonday (Desa Noongan) berjumlah 2 orang, Kt. Sungean (Desa Noongan) berjumlah 2 orang, Kt. Permata (Noongan II) berjumlah 2 orang dan Kt. Di Eden (Noongan II) berjumlah 1 orang. Berdasarkan hasil wawancara dengan PPL 2, dilihat dari Tabel 15. Tabel 15 menunjukan bahwa kelompok tani binaan PPL 2 yang terdiri atas kt. Kalooran, Kt. Laba-laba merah, Kt. Sangkakala, Kt. Tekat maju, Kt. Incaya, Kt. Anugrah perdana terartik dengan penyuluhan yang dilakukan PPL 2 karena pokok bahasan sesuai masalah yang terjadi dilapangan sehingga pengetahuan yang didapat saat penyuluhan dilakukan dengan baik. Tabel 16 menunjukan bahwa 100 persen responden (9 orang) menjawab baik sekali dengan cara pemilihan pokok bahasan dari PPL 2. Total skor yang diperoleh dari indikator ini adalah 45 . Angka indeks dari pernyataan nomor 1 yaitu : $45 / 45 \times 100 \%=100 \%$ sehingga nilai interpretasinya tergolong baik sekali.

Tabel 12. Perasaan Petani setelah mengikuti Penyuluhan dari PPL 1 (hasil wawancara dengan binaan PPL 1)

\begin{tabular}{ccccc}
\hline Alternatif Jawaban & Alternatif Skor & Jumlah Responden & $\begin{array}{c}\text { Persentase } \\
\text { Responden }\end{array}$ & Total Skor (\%) \\
\hline Baik Sekali & 5 & 5 & 55,5 & 25 \\
Baik & 4 & 4 & 44,4 & 16 \\
Sedang & 3 & - & - & - \\
Buruk & 2 & - & - & - \\
Sangat Buruk & 1 & - & - & - \\
\hline Total & & 9 & 100 & 41 \\
\hline
\end{tabular}

Sumber : Diolah dari data primer, 2016

Tabel 13. Tindakan yang dilakukan Petani setelah mengikuti Penyuluhan dari PPL 1 (hasil wawancara dengan binaan PPL 1)

\begin{tabular}{ccccc}
\hline Alternatif Jawaban & Alternatif Skor & Jumlah Responden & Persentase Responden & Total Skor (\%) \\
\hline Baik Sekali & 5 & 6 & 66,6 & 30 \\
Baik & 4 & 3 & 33,3 & 12 \\
Sedang & 3 & - & - & - \\
Buruk & 2 & - & - & - \\
Sangat Buruk & 1 & - & - & - \\
\hline Total & & 9 & 100 & 42 \\
\hline
\end{tabular}

Sumber : Diolah dari data primer, 2016 
Tabel 14. Rekapitulasi Jumlah Skor Pengambilan Data, Indeks Sikap, dan Interpretasi pada Indikator Penyuluhan PPL 1

\begin{tabular}{clccc}
\hline No & \multicolumn{1}{c}{ Pernyataan } & Total Skor & Indeks Sikap (\%) & Interpretasi \\
\hline 1. & Memilih pokok bahasan & 45 & 100 & Baik Sekali \\
\hline 2. & Berbicara di iringi bantuan gerak-gerik & 43 & 95,5 & Baik Sekali \\
\hline 3. & Alat yang dipakai saat penyuluhan & 37 & 82,2 & Baik Sekali \\
\hline 4. & Menyesuaikan situasi & 42 & 93,3 & Baik Sekali \\
\hline 5. & $\begin{array}{l}\text { Menghargai dan menghormati lawan } \\
\text { bicara dengan baik }\end{array}$ & 44 & 97,7 & Baik Sekali \\
\hline 6. & $\begin{array}{l}\text { Menganggapi setiap reaksi, saran dan } \\
\text { usul dari lawan bicara }\end{array}$ & 45 & 100 & Baik Sekali \\
\hline 7. & $\begin{array}{l}\text { Pengetahuan yang didapat Petani setelah } \\
\text { Penyuluhan dari PPL 1 }\end{array}$ & 44 & 97,7 & Baik Sekali \\
\hline 8. & $\begin{array}{l}\text { Perasaan Petani setelah mengikuti } \\
\text { Penyuluhan dari PPL 1 }\end{array}$ & 41 & 91,1 & Baik Sekali \\
\hline 9. & $\begin{array}{l}\text { Tindakan yang dilakukan Petani setelah } \\
\text { mengikuti Penyuluhan dari PPL 1 }\end{array}$ & 42 & 93,3 & Baik Sekali \\
\hline Sun & & &
\end{tabular}

Sumber : Diolah dari data primer, 2016

Tabel 15. Penyerapan Petani (Hasil wawancara dengan PPL 2)

\begin{tabular}{clc}
\hline No & Penyerapan Kelompok Tani & Hasil wawancara \\
\hline 1 & Perasaan petani (afektif) & Baik \\
2 & Pengetahuan petani (kognitif) & Sangat Baik \\
3 & Tindakan petani (motorik) & Baik
\end{tabular}

Sumber data primer, November 2016

Tabel 16. Cara pemilihan pokok bahasan dari PPL 2 (hasil wawancara dengan binaan PPL 2)

\begin{tabular}{ccccc}
\hline $\begin{array}{c}\text { Alternatif } \\
\text { Jawaban }\end{array}$ & Alternatif Skor & $\begin{array}{c}\text { Jumlah } \\
\text { Responden }\end{array}$ & $\begin{array}{c}\text { Persentase } \\
\text { Responden }\end{array}$ & $\begin{array}{c}\text { Total Skor } \\
(\%)\end{array}$ \\
\hline Baik Sekali & 5 & 9 & 100 & 45 \\
Baik & 4 & - & - & - \\
Sedang & 3 & - & - & - \\
Buruk & 2 & - & - & - \\
Sangat Buruk & 1 & - & - & - \\
\hline Total & & 9 & 100 & 45 \\
\hline
\end{tabular}

Sumber : Diolah dari data primer, 2016 
Tabel 17 menunjukan bahwa 66,6 persen responden (6 orang) menjawab baik kepada PPL 2 saat melakukan penyuluhan yang diiringi dengan gerakgerik. Sedangkan 33,3 persen responden (3 orang) menjawab baik sekali. Total skor yang diperoleh dari indikator adalah 39. Angka indeks dari pernyataan nomor 2 ini yaitu : 39 / 45 x 100\% = 86,6 sehingga interpretasinya tergolong baik sekali. Tabel 18 menunjukan bahwa 88,8 persen responden ( 8 orang) menjawab baik dengan alat yang dipakai PPL 2 saat melakukan penyuluhan. Sedangkan 11,1 persen responden (1 orang) menjawab sedang. Total skor yang diperoleh dari indikator adalah 35. Angka indeks dari pernyataan nomor 3 ini yaitu : $35 / 45$ x 100\% =77,7\% sehinggatergolong baik. Tabel 19 menunjukan bahwa 77,7 persen responden (7 orang) menjawab baik. Sedangkan 11,1 persen responden ( 1 orang) menjawab baik sekali dan 11,1 persen responden (1 orang) menjawab sedang. Total skor yang diperoleh dari indikator adalah 36. Angka indeks dari pernyataan nomor 4 yaitu : $36 / 45$ x 100\% = 80\% sehingga interpretasinya tergolong baik. Tabel 20 menunjukan bahwa 77,7 persen responden ( 7 orang) menjawab dengan pernyataan ini. Sedangkan 22,2 persen responden ( 2 orang) menjawab sedang. Total skor yang diperoleh indikator adalah 34. Angka indeks dari pernyataan nomor 5 ini yaitu : 34 / 45 x 100\% =75,5\% sehingga interpretasinya tergolong baik.

Tabel 17. Berbicara diiringi bantuan gerak-gerik (hasil wawancara dengan binaan PPL 2)

\begin{tabular}{ccccc}
\hline Alternatif Jawaban & Alternatif Skor & Jumlah Responden & Persentase Responden & Total Skor (\%) \\
\hline Baik Sekali & 5 & 3 & 33,3 & 15 \\
Baik & 4 & 6 & 66,6 & 24 \\
Sedang & 3 & - & - & - \\
Buruk & 2 & - & - & - \\
Sangat Buruk & 1 & - & - & - \\
\hline Total & & 9 & 100 & 39 \\
\hline
\end{tabular}

Sumber : Diolah dari data primer, 2016

Tabel 18. Alat yang dipakai saat penyuluhan (hasil wawancara dengan binaan PPL 2)

\begin{tabular}{ccccc}
\hline Alternatif Jawaban & Alternatif Skor & Jumlah Responden & Persentase Responden & Total Skor (\%) \\
\hline Baik Sekali & 5 & - & - & - \\
Baik & 4 & 8 & 88,8 & 32 \\
Sedang & 3 & 1 & 11,1 & 3 \\
Buruk & 2 & - & - & - \\
Sangat Buruk & 1 & - & - & - \\
\hline Total & & 9 & 100 & 35 \\
\hline
\end{tabular}

Sumber : Diolah dari data primer, 2016

Tabel 19. Menyesuaikan situasi (hasil wawancara dengan binaan PPL 2)

\begin{tabular}{ccccc}
\hline Alternatif Jawaban & Alternatif Skor & Jumlah Responden & Persentase Responden & Total Skor (\%) \\
\hline Baik Sekali & 5 & 1 & 11,1 & 5 \\
Baik & 4 & 7 & 77,7 & 28 \\
Sedang & 3 & 1 & 11,1 & 3 \\
Buruk & 2 & - & - & - \\
Sangat Buruk & 1 & - & - & - \\
\hline Total & & 9 & 100 & 36 \\
\hline
\end{tabular}

Sumber : Diolah dari data primer, 2016

Tabel 20. Menghargai dan menghormati lawan bicara dengan baik (hasil wawancara dengan binaan PPL 2)

\begin{tabular}{ccccc}
\hline Alternatif Jawaban & Alternatif Skor & Jumlah Responden & Persentase Responden & Total Skor (\%) \\
\hline Baik Sekali & 5 & - & - & - \\
Baik & 4 & 7 & 77,7 & 28 \\
Sedang & 3 & 2 & 22,2 & 6 \\
Buruk & 2 & - & - & - \\
Sangat Buruk & 1 & - & - & - \\
\hline Total & & 9 & 100 & 34
\end{tabular}

Sumber : Diolah dari data primer, 2016 
Tabel 21 menunjukan bahwa 77,7 persen responden (7 orang) menjawab baik saat PPL 2 menganggapi setiap reaksi, saran dan usul dari petani. Sedangkan 22,2 persen responden (2 orang) menjawab baik sekali. Total skor yang diperoleh dari indikator adalah 38. Angka indeks dari pernyataan nomor 6 yaitu : $38 / 45 \times 100 \%=84,4 \%$ sehingga interpretasi nilainya tergolong baik sekali. Tabel 22 menunjukan bahwa 77,7 persen responden ( 7 orang) menjawab baik dengan pengetahuan yang didapat petani sesudah mengikuti penyuluhan dari PPL 2. Sedangkan 11,1 persen responden (1 orang) menjawab baik sekali dan 11,1 persen responden (1 orang) menjawab sedang. Total skor yang diperoleh dari indikator ini adalah 36. Angka indeks dari pernyataan nomor 7 yaitu : $36 / 45 \times 100 \%=80 \%$ sehingga interpretasi nilainya tergolong baik. Tabel 23 menunjukan bahwa 77,7 persen responden (7 orang) menjawab baik. Sedangkan 22,2 persen responden (2 orang) menjawab baik sekali. Total skor yang diperoleh dari indikator adalah 38. Angka indeks dari pernyataan nomor 8 yaitu : $38 / 45 \times 100 \%=84,4 \%$ sehingga interpretasi nilainya tergolong baik sekali.

Tabel 21. Menganggapi setiap reaksi, saran, dan usul dari lawan bicara (hasil wawancara dengan binaan PPL 2)

\begin{tabular}{ccccc}
\hline Alternatif Jawaban & Alternatif Skor & Jumlah Responden & Persentase Responden & Total Skor (\%) \\
\hline Baik Sekali & 5 & 2 & 22,2 & 10 \\
Baik & 4 & 7 & 77,7 & 28 \\
Sedang & 3 & - & - & - \\
Buruk & 2 & - & - & - \\
Sangat Buruk & 1 & - & - & - \\
Total & & 9 & 100 & 38 \\
\hline
\end{tabular}

Sumber : Diolah dari data primer, 2016

Tabel 22. Pengetahuan yang didapat Petani setelah Penyuluhan dari PPL 2 (hasil wawancara dengan binaan PPL 2)

\begin{tabular}{ccccc}
\hline Alternatif Jawaban & Alternatif Skor & Jumlah Responden & Persentase Responden & Total Skor (\%) \\
\hline Baik Sekali & 5 & 1 & 11,1 & 5 \\
Baik & 4 & 7 & 77,7 & 28 \\
Sedang & 3 & 1 & 11,1 & 3 \\
Buruk & 2 & - & - & - \\
Sangat Buruk & 1 & - & - & - \\
\hline Total & & 9 & 100 & 36 \\
\hline
\end{tabular}

Sumber : Diolah dari data primer, 2016

Tabel 23. Perasaan Petani setelah mengikuti Penyuluhan dari PPL 2 (hasil wawancara dengan binaan PPL 2)

\begin{tabular}{ccccc}
\hline Alternatif Jawaban & Alternatif Skor & Jumlah Responden & Persentase Responden & Total Skor (\%) \\
\hline Baik Sekali & 5 & 2 & 22,2 & 10 \\
Baik & 4 & 7 & 77,7 & 28 \\
Sedang & 3 & - & - & - \\
Buruk & 2 & - & - & - \\
Sangat Buruk & 1 & - & - & - \\
\hline Total & & 9 & 100 & 38
\end{tabular}

Sumber : Diolah dari data primer, 2016 
Tabel 24 menunjukan bahwa 88,8 persen responden ( 8 orang ) menjawab baik. Sedangkan 11,1 persen responden (1 orang) menjawab sedang. Total skor yang diperoleh dari indikator ini adalah 35. Angka indeks dari pernyataan nomor 9 yaitu : $35 / 45 \times 100 \%=$ $77,7 \%$ sehingga interpretasi nilainya tergolong baik karena petani melakukan apa yang sudah disuluhkan PPL 2 dilapangan.

\section{Rekapitulasi Indeks dari Penyuluhan yang dilakukan PPL 2}

Rekapitulasi total skor, indeks sikap dan interpretasi dari penyuluhan yang dilakukan PPL 2. Tabel 25 menunjukkan bahwa terdapat 9 indikator yang diukur dalam penyuluhan yang dilakukan PPL 2 dimana indeks tertinggi pada pernyataan 1 mendapat indeks 100 persen.
Sedangkan pernyataan 2 mendapat indeks 86,6 persen, pernyataan 6 dan 8 mendapat indeks 84,4 , pernyataan 4 dan 7 mendapat indeks 80 persen, pernyataan 3 dan 9 mendapat indeks 77,7 persen dan pernyataan 5 mendapat indeks 75,5 persen. Dan semua indeks mendapat interpretasi sangat baik, karena interpretasi dengan angka 61 persen- 81 persen itu baik dalam teori Likert yang dikatakan oleh Ridwan (2010). Hasil ini diperoleh dari wawancara langsung dengan Kt. Kalooran (Desa Tounelet) berjumlah 1 orang, Kt. Laba-laba Merah (Desa Tounelet) berjumlah 1 orang, Kt. Sangkakala (Desa Koyawas) berjumlah 1 orang, Kt. Tekat Maju (Koyawas) berjumlah 2 orang, Kt. Incaya (Desa Paslaten) berjumlah 2 orang, Kt. Anugrah Perdana (Lowian) berjumlah 2 orang.

Tabel 24. Tindakan yang dilakukan Petani setelah mengikuti Penyuluhan dari PPL 2 (hasil wawancara dengan binaan PPL 2)

\begin{tabular}{ccccc}
\hline Alternatif Jawaban & Alternatif Skor & Jumlah Responden & Persentase Responden & Total Skor (\%) \\
\hline Baik Sekali & 5 & - & - & - \\
Baik & 4 & 8 & 88,8 & 32 \\
Sedang & 3 & 1 & 11,1 & 3 \\
Buruk & 2 & - & - & - \\
Sangat Buruk & 1 & - & - & - \\
\hline Total & & 9 & 100 & 35 \\
\hline
\end{tabular}

Sumber : Diolah dari data primer, 2016

Tabel 25. Rekapitulasi Jumlah Skor Pengambilan Data, Indeks Sikap, dan Interpretasi pada Indikator Penyuluhan PPL 2

\begin{tabular}{lllll}
\hline No & \multicolumn{1}{c}{ Pernyataan } & Total Skor & Indeks Sikap (\%) & Interpretasi \\
\hline 1. & Memilih pokok bahasan & 45 & 100 & Baik Sekali \\
\hline 2. & Berbicara di iringi bantuan gerak-gerik & 39 & 86,6 & Baik Sekali \\
\hline 3. & Alat yang dipakai saat penyuluhan & 35 & 77,7 & Baik \\
\hline 4. & Menyesuaikan situasi & 36 & 80 & Baik \\
\hline 5. & $\begin{array}{l}\text { Menghargai dan menghormati lawan bicara } \\
\text { dengan baik }\end{array}$ & 34 & 75,5 & Baik \\
\hline 6. & $\begin{array}{l}\text { Menganggapi setiap reaksi, saran dan usul dari } \\
\text { lawan bicara }\end{array}$ & 38 & 84,4 & Baik Sekali \\
\hline 7. & $\begin{array}{l}\text { Pengetahuan yang didapat Petani setelah } \\
\text { Penyuluhan dari PPL 2 }\end{array}$ & 36 & 80 & Baik \\
\hline 8. & $\begin{array}{l}\text { Perasaan Petani setelah mengikuti Penyuluhan } \\
\text { dari PPL 2 }\end{array}$ & 38 & 84,4 & Baik Sekali \\
\hline 9. & $\begin{array}{l}\text { Tindakan yang dilakukan Petani setelah } \\
\text { mengikuti Penyuluhan dari PPL 2 }\end{array}$ & 35 & 77,7 & Baik \\
\hline
\end{tabular}

Sumber : Diolah dari data primer, 2016 
Berdasarkan hasil wawancara dengan PPL 3, dapat dilihat pada Tabel 26. Menurut hasil wawancara, penyuluhan dilakukan dengan memakai teknik komunikasi yang baik. Pemilihan pokok bahasan diambil dari masalah yang terjadi dilapangan sehingga petani tertarik mengikuti penyuluhan dan dapat mengerti serta melakukan materi yang disuluhkan dengan baik. Alat yang dipakai hanya memakai alat tulis menulis dan biasanya hanya dilakukan secara face to face. Tabel 27 menunjukan bahwa 100 persen resonden ( 9 orang) menjawab baik sekali dengan cara PPL 3 memilih pokok bahasan yang disuluhkan saat penyuluhan. Total skor yang diperoleh dari indikator ini adalah 45. Angka indeks dari pernyataan nomor 1 ini yaitu : 45 / 45 $\mathrm{x} 100 \%=100 \%$ sehingga interpretasi nilainya tergolong baik sekali karena PPL 3 memilih pokok bahasan yang disuluhkan sesuai masalah yang terjadi dilapangan. Tabel 28 menunjukan bahwa 44,4 persen responden (4 orang) menjawab baik. Sedangkan 55,5 persen responden (5 orang) menjawab sedang. Total skor yang diperoleh dari indikator ini adalah 31. Angka indeks dari pernyataan nomor 2 yaitu : $31 / 45 \times 100 \%=$ $68 \%$ sehingga interpretasi nilainya tergolong baik karena PPL 3 melakukan bantuan gerakgerik saat melakukan penyuluhan kepada petani. Tabel 29 menunjukan bahwa 77,7 persen responden (7 orang) menjawab sedang dengan alat yang dipakai PPL 3 saat penyuluhan. Sedangkan 22,2 persen responden (2 orang) menjawab baik. Total skor yang diperoleh dari indikator ini adalah 29. Angka indeks dari pernyataan nomor 3 yaitu : 64,4\% sehingga interpretasi nilainya tergolong baik karena PPL 3 memakai alat penunjang saat melakukan penyuluhan.

Tabel 26. Penyerapan Petani (Hasil wawancara dengan PPL 3)

\begin{tabular}{clc}
\hline No & Penyerapan Kelompok Tani & Hasil wawancara \\
\hline 1 & Perasaan petani (afektif) & Baik \\
2 & Pengetahuan petani (kognitif) & Baik \\
3 & Tindakan petani (motorik) & Baik \\
\hline
\end{tabular}

Sumber data primer, November 2016

Tabel 27. Cara pemilihan pokok bahasan dari PPL 3 (hasil wawancara dengan binaan PPL 3)

\begin{tabular}{ccccc}
\hline $\begin{array}{c}\text { Alternatif } \\
\text { Jawaban }\end{array}$ & Alternatif Skor & Jumlah Responden & Persentase Responden & Total Skor (\%) \\
\hline Baik Sekali & 5 & 9 & 100 & 45 \\
Baik & 4 & - & - & - \\
Sedang & 3 & - & - & - \\
Buruk & 2 & - & - & - \\
Sangat Buruk & 1 & - & - & - \\
\hline Total & & 9 & 100 & 45 \\
\hline
\end{tabular}

Sumber : Diolah dari data primer, 2016

Tabel 28. Berbicara diiringi bantuan gerak-gerik (hasil wawancara dengan binaan PPL 3)

\begin{tabular}{ccccc}
\hline Alternatif Jawaban & Alternatif Skor & Jumlah Responden & Persentase Responden & Total Skor (\%) \\
\hline Baik Sekali & 5 & - & - & - \\
Baik & 4 & 4 & 44,4 & 16 \\
Sedang & 3 & 5 & 55,5 & 15 \\
Buruk & 2 & - & - & - \\
Sangat Buruk & 1 & - & - & - \\
\hline Total & & 9 & 100 & 31 \\
\hline
\end{tabular}

Sumber : Diolah dari data primer, 2016 
Tabel 29 menunjukan bahwa 77,7 persen responden ( 7 orang) menjawab sedang dengan alat yang dipakai PPL 3 saat penyuluhan. Sedangkan 22,2 persen responden (2 orang) menjawab baik. Total skor yang diperoleh dari indikator ini adalah 29. Angka indeks dari pernyataan nomor 3 yaitu : 64,4\% sehingga interpretasi nilainya tergolong baik karena PPL 3 memakai alat penunjang saat melakukan penyuluhan. Tabel 30 menunjukan bahwa 88,8 persen responden ( 8 orang) menjawab sedang, sedangkan 11,1 persen responden menjawab baik. Total skor yang diperoleh dari indikator ini adalah 28. Angka indeks dari pernyataan nomor 4 yaitu : 28 / 45 x $100 \%=62,2 \%$ sehingga interpretasi nilainya tergolong baik karena PPL 3 dapat menyesuaikan situasi saat melakukan penyuluhan. Tabel 31 menunjukan bahwa 77,7 persen responden (7 orang) menjawab sedang. Sedangkan 22,2 persen responden menjawab baik. Total skor yang diperoleh dari indikator ini adalah 29. Angka indeks dari pernyataan nomor 5 yaitu : 29 / $45 \mathrm{x}$ $100 \%=64,4 \%$ sehingga interpretasi nilainya tergolong baik karena PPL 3 menghargai dan menghormati petani saat penyuluhan.

Tabel 29. Alat yang dipakai saat penyuluhan (hasil wawancara dengan binaan PPL 3)

\begin{tabular}{ccccc}
\hline $\begin{array}{c}\text { Alternatif } \\
\text { Jawaban }\end{array}$ & Alternatif Skor & Jumlah Responden & $\begin{array}{c}\text { Persentase } \\
\text { Responden }\end{array}$ & Total Skor (\%) \\
\hline Baik Sekali & 5 & - & - & - \\
Baik & 4 & 2 & 22,2 & 8 \\
Sedang & 3 & 7 & - & 21 \\
Buruk & 2 & - & - & - \\
Sangat Buruk & 1 & - & 100 & - \\
\hline Total & & 9 & & \\
\hline
\end{tabular}

Sumber : Diolah dari data primer, 2016

Tabel 30. Menyesuaikan situasi (hasil wawancara dengan binaan PPL 3)

\begin{tabular}{ccccc}
\hline $\begin{array}{c}\text { Alternatif } \\
\text { Jawaban }\end{array}$ & Alternatif Skor & Jumlah Responden & $\begin{array}{c}\text { Persentase } \\
\text { Responden }\end{array}$ & Total Skor (\%) \\
\hline Baik Sekali & 5 & - & - & - \\
Baik & 4 & 1 & 11,1 & 4 \\
Sedang & 3 & 8 & 88,8 & 24 \\
Buruk & 2 & - & - & - \\
Sangat Buruk & 1 & - & - & - \\
\hline Total & & 9 & 100 & 28 \\
\hline
\end{tabular}

Sumber : Diolah dari data primer, 2016

Tabel 31. Menghargai dan menghormati lawan bicara dengan baik (hasil wawancara dengan binaan PPL 3)

\begin{tabular}{ccccc}
\hline Alternatif & Alternatif Skor & Jumlah Responden & Persentase Responden & Total Skor (\%) \\
Jawaban & & & - & - \\
\hline Baik Sekali & 5 & - & 22,2 & 8 \\
Baik & 4 & 2 & 77,7 & 21 \\
Sedang & 3 & - & - & - \\
Buruk & 2 & - & - & - \\
Sangat Buruk & 1 & 9 & 100 & 29 \\
\hline Total & & & &
\end{tabular}

Sumber : Diolah dari data primer, 2016 
Tabel 32 menunjukan bahwa 77,7 persen responden (7 orang) menjawab baik. Sedangkan 22,2 persen responden ( 2 orang) menjawab sedang. Total skor yang diperoleh dari indikator ini adalah 34. Angka indeks dari pernyataan nomor 6 yaitu : 34 / 45 x 100\% $=75,5 \%$ sehingga interpretasi nilainya tergolong baik karena PPL 3 dapat menganggapi setiap reaksi, saran dan usul dari petani. Tabel 33 menunjukan bahwa 77,7 persen responden ( 7 orang) menjawab sedang. Sedangkan 22,2 persen responden (2 orang) menjawab baik. Total skor yang diperoleh dari indikator ini adalah 29. Angka indeks dari pernyataan nomor 7 yaitu : $29 / 45 \times 100 \%=$ $64,4 \%$ sehingga interpretasi nilainya tergolong baik. Tabel 34 menunjukan bahwa 88,8 persen responden ( 8 orang) menjawab baik. Sedangkan 11,1 persen responden (1 orang) menjawab sedang. Total skor yang diperoleh dari indikator ini adalah 35. Angka indeks dari pernyataan nomor 8 yaitu : $35 / 45 \times 100 \%=77,7 \%$ sehingga interpretasi nilainya tergolong baik. Tabel 35 menunjukan bahwa 88,8 persen responden (8 orang) menjawab sedang. Sedangkan 11,1 persen responden (1 orang) menjawab baik. Total skor yang diperoleh dari indikator ini adalah 28. Angka indeks dari pernyataan nomo 8 yaitu : $28 / 45 \times 100 \%=$ $62,2 \%$ sehingga interpretasi nilainya tergolong baik.

Tabel 32. Menganggapi setiap reaksi, saran, dan usul dari lawan bicara (hasil wawancara dengan binaan PPL 3)

\begin{tabular}{ccccc}
\hline Alternatif Jawaban & Alternatif Skor & Jumlah Responden & Persentase Responden & Total Skor (\%) \\
\hline Baik Sekali & 5 & - & - & - \\
Baik & 4 & 7 & 77,7 & 28 \\
Sedang & 3 & 2 & 22,2 & 6 \\
Buruk & 2 & - & - & - \\
Sangat Buruk & 1 & - & - & - \\
\hline Total & & 9 & 100 & 34 \\
\hline
\end{tabular}

Sumber : Diolah dari data primer, 2016

Tabel 33. Pengetahuan yang didapat Petani setelah Penyuluhan dari PPL 3 (hasil wawancara dengan binaan PPL 3)

\begin{tabular}{ccccc}
\hline Alternatif Jawaban & Alternatif Skor & Jumlah Responden & Persentase Responden & Total Skor (\%) \\
\hline Baik Sekali & 5 & - & - & - \\
Baik & 4 & 2 & 22,2 & 8 \\
Sedang & 3 & 7 & 77,7 & 21 \\
Buruk & 2 & - & - & - \\
Sangat Buruk & 1 & - & - & - \\
\hline Total & & 9 & 100 & 29 \\
\hline
\end{tabular}

Sumber : Diolah dari data primer, 2016

Tabel 34. Perasaan Petani setelah mengikuti Penyuluhan dari PPL 3 (hasil wawancara dengan binaan PPL 3)

\begin{tabular}{ccccc}
\hline Alternatif Jawaban & Alternatif Skor & Jumlah Responden & Persentase Responden & Total Skor (\%) \\
\hline Baik Sekali & 5 & - & - & - \\
Baik & 4 & 8 & 88,8 & 32 \\
Sedang & 3 & 1 & 1,11 & 3 \\
Buruk & 2 & - & - & - \\
Sangat Buruk & 1 & - & - & - \\
\hline Total & & 9 & 100 & 35 \\
\hline
\end{tabular}

Sumber : Diolah dari data primer, 2016 
Rekapitulasi Indeks dari Penyuluhan yang dilakukan PPL 3

Tabel 36 menunjukkan rekapitulasi total skor, indeks sikap dan interpretasi dari penyuluhan yang dilakukan PPL 3. Tabel 36 menunjukkan terdapat 9 indikator yang diukur dalam penyuluhan yang dilakukan PPL 3 dimana indeks tertinggi terdapat pada pernyataan 1 mendapat 100 persen, sedangkan pernyataan 8 mendapat indeks 77,7 persen, pernyataan 6 mendapat indeks 75,5 persen, pernyataan 2 mendapat indeks 68, pernyataan 5,6 dan 7 mendapat 64,4 persen, pernyataan 4 dan 9 mendapat indeks 62,2 persen. Dan indeks yang diperoleh dari penyuluhan PPL 3 mendapat interpretasi baik. Hasil ini diperoleh dari hasil wawancara dengan Kt. Suka Maju (Kopiwangker) berjumlah 1 orang, Kt. Tumou Tou (Desa Kopiwangker) berjumlah 3 orang, Kt. Pelangi Kasih (Desa Noongan III) berjumlah 2 orang, dan Kt. Victori (Raranon) berjumlah 3 orang.

Berdasarkan hasil wawancara dengan PPL 4, dapat dilihat pada Tabel 37. Menurut hasil wawancara dengan PPL 4, rata-rata petani yang mengikuti penyuluhan sangat tertarik dengan penyuluhan yang dilakukan. Pengetahuan yang didapat petani sangat baik dan dilakukan dilapangan.

Tabel 35. Tindakan yang dilakukan Petani setelah mengikuti Penyuluhan dari PPL 3 (hasil wawancara dengan binaan PPL 3)

\begin{tabular}{ccccc}
\hline Alternatif Jawaban & Alternatif Skor & Jumlah Responden & Persentase Responden & Total Skor (\%) \\
\hline Baik Sekali & 5 & - & - & - \\
Baik & 4 & 1 & 11,1 & 4 \\
Sedang & 3 & 8 & 88,8 & 24 \\
Buruk & 2 & - & - & - \\
Sangat Buruk & 1 & - & - & - \\
\hline Total & & 9 & 100 & 28 \\
\hline
\end{tabular}

Sumber : Diolah dari data primer, 2016

Tabel 36. Rekapitulasi Jumlah Skor Pengambilan Data, Indeks Sikap, dan Interpretasi pada Indikator Penyuluhan PPL 3

\begin{tabular}{llccc}
\hline No & \multicolumn{1}{c}{ Pernyataan } & Total Skor & Indeks Sikap (\%) & Interpretasi \\
\hline 1. & Memilih pokok bahasan & 45 & 100 & Baik Sekali \\
\hline 2. & Berbicara di iringi bantuan gerak-gerik & 31 & 68 & Baik \\
\hline 3. & Alat yang dipakai saat penyuluhan & 29 & 64,4 & Baik \\
\hline 4. & Menyesuaikan situasi & 28 & 62,2 & Baik \\
\hline 5. & $\begin{array}{l}\text { Menghargai dan menghormati lawan bicara } \\
\text { dengan baik }\end{array}$ & 29 & 64,4 & Baik \\
\hline 6. & $\begin{array}{l}\text { Menganggapi setiap reaksi, saran dan usul dari } \\
\text { lawan bicara }\end{array}$ & 34 & 75,5 & Baik \\
\hline 7. & $\begin{array}{l}\text { Pengetahuan yang didapat Petani setelah } \\
\text { Penyuluhan dari PPL 3 }\end{array}$ & 29 & 64,4 & Baik \\
\hline 8. & $\begin{array}{l}\text { Perasaan Petani setelah mengikuti Penyuluhan } \\
\text { dari PPL 3 }\end{array}$ & 35 & 77,7 & Baik \\
\hline 9. & $\begin{array}{l}\text { Tindakan yang dilakukan Petani setelah } \\
\text { mengikuti Penyuluhan dari PPL 3 }\end{array}$ & 28 & 2,2 & \multirow{2}{*}{ B } \\
\hline
\end{tabular}

Sumber : Diolah dari data primer, 2016

Tabel 37. Penyerapan Petani (Hasil wawancara dengan PPL 4)

\begin{tabular}{cll}
\hline No & Penyerapan Kelompok Tani & Hasil wawancara \\
\hline 1 & Perasaan petani (afektif) & Sangat Baik \\
2 & Pengetahuan petani (kognitif) & Sangat Baik \\
3 & Tindakan petani (motorik) & Sangat Baik \\
\hline
\end{tabular}

Sumber data primer, November 2016 
Tabel 38 menunjukan bahwa 100 persen responden ( 9 orang) menjawab baik sekali. Total skor yang diperoleh dari indikator ini adalah 45 . Angka indeks dari pernyataan nomor 1 yaitu 45 / 45 $\mathrm{x} 100 \%=100 \%$ sehingga interpretasi nilainya tergolong baik sekali karena PPL 4 memilih pokok bahasan yang disuluhkan sesuai masalah yang terjadi dilapangan.Tabel 39 menunjukan bahwa 66,6 persen responden ( 6 orang) menjawab baik. Sedangkan 33,3 persen responden (3 orang) menjawab baik sekali. Total skor yang diperoleh dari indikator ini adalah 39. Angka indeks dari pernyataan nomor 2 yaitu : 39 / 45 x 100\%= $86,6 \%$ sehingga interpretasi nilainya tergolong baik sekali karena PPL 4 melakukan bantuan gerak-gerik saat melakukan penyuluhan kepada petani. Tabel 39 menunjukan bahwa 88,8 persen responden ( 8 orang) menjawab baik. Sedangkan 11,1 persen responden (1 orang) menjawab sedang. Total skor yang diperoleh dari indikator ini adalah 35. Angka indeks dari pernyataan nomor 3 yaitu : 35 / 45 x 100\%= $77,7 \%$ sehingga interpretasi nilainya tergolong baik karena alat yang dipakai PPL 4 dapat membantu saat penyuluhan. Tabel 40 menunjukan bahwa 77,7 persen responden ( 7 orang) menjawab baik terhadap penyesuaian situasi yang dilakukan PPL 4. Sedangkan 33,3 persen responden (3 orang) menjawab sedang. Total skor yang diperoleh dari indikator ini adalah 36. Angka indeks dari pernyataan nomor 4 yaitu $36 / 45 \times 100 \%=80 \%$ sehingga interpretasi nilainya tergolong baik sekali.

Tabel 38. Cara pemilihan pokok bahasan dari PPL 4 (hasil wawancara dengan binaan PPL 4)

\begin{tabular}{ccccc}
\hline Alternatif Jawaban & Alternatif Skor & Jumlah Responden & Persentase Responden & Total Skor (\%) \\
\hline Baik Sekali & 5 & 9 & 100 & 45 \\
Baik & 4 & - & - & - \\
Sedang & 3 & - & - & - \\
Buruk & 2 & - & - & - \\
Sangat Buruk & 1 & - & - & - \\
\hline Total & & 9 & 100 & 45 \\
\hline
\end{tabular}

Sumber : Diolah dari data primer, 2016

Tabel 39. Berbicara diiringi bantuan gerak-gerik (hasil wawancara dengan binaan PPL 4)

\begin{tabular}{ccccc}
\hline Alternatif Jawaban & Alternatif Skor & Jumlah Responden & Persentase Responden & Total Skor (\%) \\
\hline Baik Sekali & 5 & 3 & 33,3 & 15 \\
Baik & 4 & 6 & 66,6 & 24 \\
Sedang & 3 & - & - & - \\
Buruk & 2 & - & - & - \\
Sangat Buruk & 1 & - & - & - \\
\hline Total & & 9 & 100 & 39
\end{tabular}

Sumber : Diolah dari data primer, 2016

JK

Tabel 40. Alat yang dipakai saat penyuluhan (hasil wawancara dengan binaan PPL 4)

\begin{tabular}{ccccc}
\hline Alternatif Jawaban & Alternatif Skor & Jumlah Responden & Persentase Responden & Total Skor (\%) \\
\hline Baik Sekali & 5 & - & - & - \\
Baik & 4 & 8 & 88,8 & 32 \\
Sedang & 3 & 1 & 11,1 & 3 \\
Buruk & 2 & - & - & - \\
Sangat Buruk & 1 & - & - & - \\
\hline Total & & 9 & 100 & 35
\end{tabular}

Sumber : Diolah dari data primer, 2016

Tabel 41. Menyesuaikan situasi (hasil wawancara dengan binaan PPL 4)

\begin{tabular}{ccccc}
\hline Alternatif Jawaban & Alternatif Skor & Jumlah Responden & Persentase Responden & Total Skor $(\%)$ \\
\hline Baik Sekali & 5 & - & - & - \\
Baik & 4 & 8 & 77,7 & 32 \\
Sedang & 3 & 1 & 11,1 & 3 \\
Buruk & 2 & - & - & - \\
Sangat Buruk & 1 & - & - & - \\
\hline Total & & 9 & 100 & 36 \\
\hline
\end{tabular}

Sumber : Diolah dari data primer, 2016 
Hasil penelitian menunjukkan 100 persen responden ( 9 orang) menjawab baik. Total skor yang diperoleh dari indikator ini adalah 36. Angka indeks dari pernyataan nomor 5 yaitu : $36 / 45 \times 100 \%=$ $80 \%$ sehingga interpretasi nilainya tergolong baik sekali karena PPL 4 dapat menghargai dan menghormati petani saat melakukan penyuluhan. Hasil penelitian menunjukkan 88,8 persen responden (8 orang) menjawab baik. Sedangkan 11,1 persen responden (1 orang) menjawab baik sekali. Total skor yang diperoleh dari indikator ini adalah 37 . Angka indeks dari pernyataa nomor 6 ini yaitu : 37 / $45 \times 100 \%=82,2 \%$ sehingga interpretasi nilainya tergolong baik sekali karena PPL 3 dapat menganggapi setiap reaksi, saran dan usul dari petani. Hasil penelitian menunjukkan 100 persen responden (9 orang) menjawab baik. Total skor yang diperoleh dari indikator ini adalah 36. Angka indeks dari pernyataan nomor 7 ini yaitu : 36 / 45 x 100\%= $80 \%$ sehingga interpretasi nilainya tergolong baik sekali. Hasil penelitian menunjukkan 100 persen responden (9 orang) menjawab baik. Total skor yang diperoleh dari indikator ini adalah 36. Angka indeks dari pernyataan nomor 8 ini yaitu : $36 / 45 \times 100 \%=$ $80 \%$ sehingga interpretasi nilainya tergolong baik sekali.

Tabel 42. Menghargai dan menghormati lawan bicara dengan baik (hasil wawancara dengan binaan PPL 4)

\begin{tabular}{ccccc}
\hline Alternatif Jawaban & Alternatif Skor & Jumlah Responden & Persentase Responden & Total Skor $(\%)$ \\
\hline Baik Sekali & 5 & - & - & - \\
Baik & 4 & 9 & 100 & 36 \\
Sedang & 3 & - & - & - \\
Buruk & 2 & - & - & - \\
Sangat Buruk & 1 & - & - & - \\
\hline Total & & 9 & 100 & 36 \\
\hline
\end{tabular}

Sumber : Diolah dari data primer, 2016

Tabel 43. Menganggapi setiap reaksi, saran, dan usul dari lawan bicara (hasil wawancara dengan binaan PPL 4)

\begin{tabular}{ccccc}
\hline Alternatif Jawaban & Alternatif Skor & Jumlah Responden & Persentase Responden & Total Skor (\%) \\
\hline Baik Sekali & 5 & 1 & 11,1 & 5 \\
Baik & 4 & 8 & 88,8 & 32 \\
Sedang & 3 & - & - & - \\
Buruk & 2 & - & - & - \\
Sangat Buruk & 1 & - & - & - \\
\hline Total & & 9 & 100 & 37 \\
\hline
\end{tabular}

Sumber : Diolah dari data primer, 2016

Tabel 44. Pengetahuan yang didapat Petani setelah Penyuluhan dari PPL 4 (hasil wawancara dengan binaan PPL 4)

\begin{tabular}{ccccc}
\hline Alternatif Jawaban & Alternatif Skor & Jumlah Responden & Persentase Responden & Total Skor $(\%)$ \\
\hline Baik Sekali & 5 & - & - & - \\
Baik & 4 & 9 & 100 & 36 \\
Sedang & 3 & - & - & - \\
Buruk & 2 & - & - & - \\
Sangat Buruk & 1 & - & - & - \\
\hline Total & & 9 & 100 & 36
\end{tabular}

Sumber : Diolah dari data primer, 2016

Tabel 45. Perasaan Petani setelah mengikuti Penyuluhan dari PPL 4 (hasil wawancara dengan binaan PPL 4)

\begin{tabular}{ccccc}
\hline Diternatif Jawaban & Alternatif Skor & Jumlah Responden & Persentase Responden & Total Skor (\%) \\
\hline Baik Sekali & 5 & - & - & - \\
Baik & 4 & 9 & 100 & 36 \\
Sedang & 3 & - & - & - \\
Buruk & 2 & - & - & - \\
Sangat Buruk & 1 & - & - & - \\
\hline Total & & 9 & 100 & 36 \\
\hline
\end{tabular}

Sumber : Diolah dari data primer, 2016 
Tabel 48 menunjukan bahwa 77,7 persen responden (7 orang) menjawab baik. Sedangkan 33,3 persen responden (3 orang) menjawab sedang. Total skor yang diperoleh dari indikator ini adalah 37. Angka indeks dari pernyataan nomor 9 ini yaitu : 37 / $45 \times 100 \%=$ $82,2 \%$ sehingga interpretasi nilainya tergolong baik sekali.

\section{Rekapitulasi Indeks dari Penyuluhan yang dilakukan PPL 4}

Tabel 47 menunjukkan rekapitulasi total skor, indeks sikap dan interpretasi dari penyuluhan yang dilakukan PPL 4. Tabel 47 menunjukkan terdapat 9 indikator yang diukur dari penyuluhan yang dilakukan PPL 4 dimana indeks tertinggi terdapat pada pernyataan 1 mendapat indeks 100 persen. Sedangkan pernyataan 2 mendapat indeks 86,6 persen, pernyataan 6 dan 9 mendapat indeks 82,2 persen, pernyataan $4,5,7$ dan 8 mendapat indeks 80 persen, pernyataan 3 mendapat indeks 77,7 persen. Dan interpretasi penyuluhan dari PPL 4 tergolong baik. Hasil ini diperoleh dari wawancara langsung dengan Kt. Sabua (Desa Ampreng) berjumlah 2 orang, Kt. Cinta Desa (Desa Tumaratas) berjumlah 2 orang, Kt. Tunas Muda (Desa Tumaratas II) berjumlah 1 orang, Kt. Loorenta (Desa Tumaratas II) bejumlah 1 orang, Kt. Pinebelian (Desa Tumaratas II) berjumlah 1 orang, Kt. Soputan (Desa Tumaratas) berjumlah 2 orang.

Tabel 46. Tindakan yang dilakukan Petani setelah mengikuti Penyuluhan dari PPL 4 (hasil wawancara dengan binaan PPL 4)

\begin{tabular}{ccccc}
\hline $\begin{array}{c}\text { Alternatif } \\
\text { Jawaban }\end{array}$ & $\begin{array}{c}\text { Alternatif } \\
\text { Skor }\end{array}$ & Jumlah Responden & Persentase Responden & Total Skor (\%) \\
\hline Baik Sekali & 5 & - & - & - \\
Baik & 4 & 7 & 77,7 & 28 \\
Sedang & 3 & 3 & 33,3 & 9 \\
Buruk & 2 & - & - & - \\
Sangat Buruk & 1 & - & - & 37 \\
\hline Total & & 9 & 100 & \\
\hline
\end{tabular}

Sumber : Diolah dari data primer, 2016

Tabel 47. Rekapitulasi Jumlah Skor Pengambilan Data, Indeks Sikap, dan Interpretasi pada Indikator Penyuluhan PPL 4

\begin{tabular}{llccc}
\hline No & \multicolumn{1}{c}{ Pernyataan } & Total Skor & Indeks Sikap (\%) & Interpretasi \\
\hline 1. & Memilih pokok bahasan & 45 & 100 & Baik Sekali \\
\hline 2. & Berbicara di iringi bantuan gerak-gerik & 39 & 86,6 & Baik Sekali \\
\hline 3. & Alat yang dipakai saat penyuluhan & 35 & 77,7 & Baik \\
\hline 4. & Menyesuaikan situasi & 36 & 80 & Baik \\
\hline 5. & $\begin{array}{l}\text { Menghargai dan menghormati lawan bicara } \\
\text { dengan baik }\end{array}$ & 36 & 80 & Baik \\
\hline 6. & $\begin{array}{l}\text { Menganggapi setiap reaksi, saran dan usul } \\
\text { dari lawan bicara }\end{array}$ & 37 & 82,2 & Baik Sekali \\
\hline 7. & $\begin{array}{l}\text { Pengetahuan yang didapat Petani setelah } \\
\text { Penyuluhan dari PPL 4 }\end{array}$ & 36 & 80 & Baik \\
\hline 8. & $\begin{array}{l}\text { Perasaan Petani setelah mengikuti } \\
\text { Penyuluhan dari PPL 4 }\end{array}$ & 36 & 80 & Baik \\
\hline 9. & $\begin{array}{l}\text { Tindakan yang dilakukan Petani setelah } \\
\text { mengikuti Penyuluhan dari PPL 4 }\end{array}$ & 37 & 82,2 & Baik Sekali \\
\hline Sun
\end{tabular}

Sumber : Diolah dari data primer, 2016 
Perhitungan hasil rekapitulasi dari Komunikasi Penyuluhan PPL 1, PPL 2, PPL 3 dan PPL 4

Untuk mengetahui peran komunikasi penyuluhan dalam penerapan teknologi usahatani yang ada di Kecamatan Langowan Barat maka perlu dilakukan perhitungan. Hasil skor yang diperoleh PPL 1 dalam peran komunikasi penyuluhan yang dilakukan pada kelompok tani Desa Raringis, Desa Raringis Selatan, Desa Noongan dan Desa Noongan 2 adalah 383. Pada penelitian ini, jumlah skor ideal (skor tertinggi), yaitu mencapai 405 (tinggi) dan jumlah skor terendah 81 (rendah). Berdasarkan data yang dihimpun dari 9 pernyataan untuk masing-masing responden (kelompok tani) maka diperoleh total skor 405 dengan letak indeks ditentukan berdasarkan skala likert berikut:

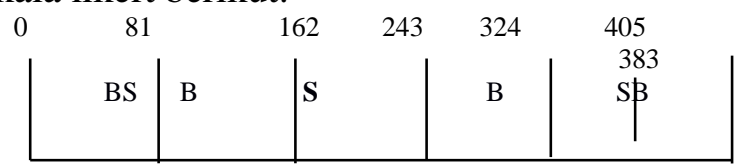

Secara presentase, angka indeks komunikasi penyuluhan PPL 1 dalam teknologi usahatani terletak pada :

Total skor $=\frac{\text { JumlahSkorHasilPengumpulanData }}{\text { JumlahSkorIdeal }(\text { Tertinggi })} \times 100 \%$

$$
=\frac{383}{405} \times 100 \%=94,56 \%
$$

Dengan interpretasi nilai:

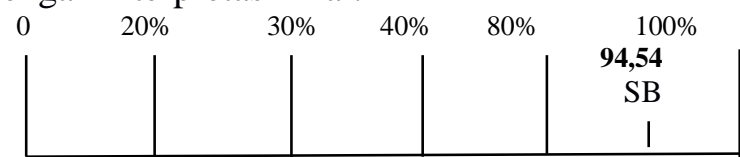

Berdasarkan hasil analisis menggunakkan skala likert, maka dapat diketahui bahwa peran komunikasi penyuluhan dari PPL 1 dalam teknologi usahatani berada pada titik $94,56 \%$ dan tergolong sangat baik. Hasil skor yang diperoleh PPL 2 dalam peran komunikasi penyuluhan yang dilakukan pada kelompok tani Desa Lowian , Desa Tounelet, Desa Paslaten, dan Desa Koyawas adalah 336. Pada penelitian ini, jumlah skor ideal (skor tertinggi), yaitu mencapai 405 (tinggi) dan jumlah skor terendah 81 (rendah). Berdasarkan data yang dihimpun dari 9 pernyataan untuk masing-masing responden (kelompok tani) maka diperoleh total skor 405 dengan letak indeks ditentukan

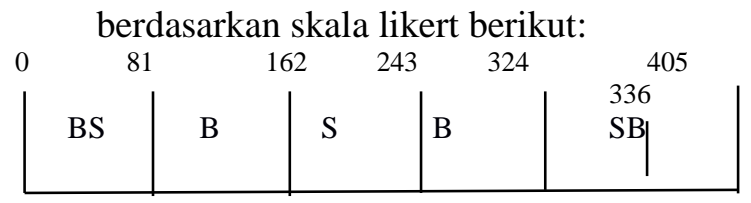

Secara presentase, angka indeks komunikasi penyuluhan PPL 2 dalam teknologi usahatani terletak pada :

Total skor $=\frac{\text { JumlahSkorHasilPengumpulanData }}{\text { JumlahSkorIdeal }(\text { Tertinggi })} \times 100 \%$

$$
=\frac{336}{405} \times 100 \%=82,96 \%
$$

Dengan interpretasi nilai:

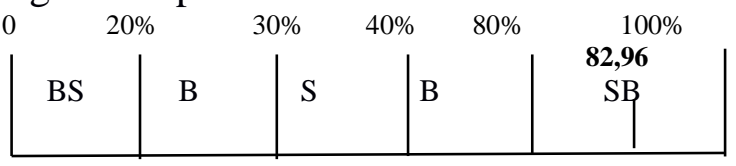

Berdasarkan hasil analisis menggunakkan skala likert, maka dapat diketahui bahwa peran komunikasi penyuluhan dari PPL 2 dalam teknologi usahatani berada pada titik $82,96 \%$ dan tergolong sangat baik. Hasil skor yang diperoleh PPL 3 dalam peran komunikasi penyuluhan yang dilakukan pada kelompok tani Desa Kopiwangker, Desa Walewangko, Desa Raranon dan Desa Noongan III adalah 288. Pada penelitian ini, jumlah skor ideal (skor tertinggi), yaitu mencapai 405 (tinggi) dan jumlah skor terendah 81 (rendah). Berdasarkan data yang dihimpun dari 9 pernyataan untuk masing-masing responden (kelompok tani) maka diperoleh total skor 405 dengan letak indeks ditentukan berdasarkan skala likert berikut:

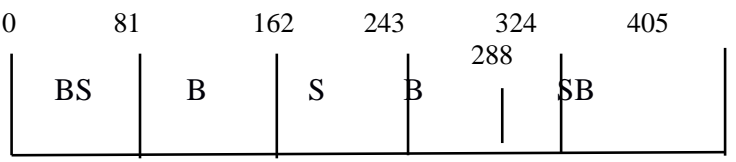

Secara presentase, angka indeks komunikasi penyuluhan PPL 3 dalam teknologi usahatani terletak pada :

Total skor $=\frac{\text { JumlahSkorHasilPengumpulanData }}{\text { JumlahSkorIdeal }(\text { Tertinggi })} \times 100 \%$

$$
=\frac{288}{405} \times 100 \%=71,11 \%
$$

Dengan interpretasi nilai:

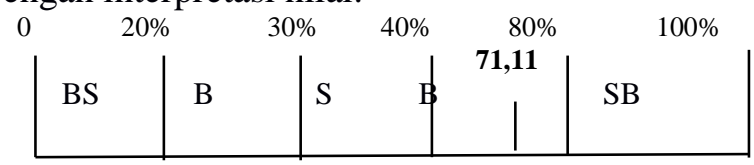


Berdasarkan hasil analisis menggunakkan skala likert, maka dapat diketahui bahwa peran komunikasi penyuluhan dari PPL 3 dalam teknologi usahatani berada pada titik $71,11 \%$ dan tergolong baik. Hasil skor yang diperoleh PPL 4 dalam peran komunikasi penyuluhan yang dilakukan pada kelompok tani Desa Tumaratas, Desa Tumaratas II, Desa Ampreng, dan Desa Raringis Utara adalah 337. Pada penelitian ini, jumlah skor ideal (skor tertinggi), yaitu mencapai 405 (tinggi) dan jumlah skor terendah 81 (rendah). Berdasarkan data yang dihimpun dari 9 pernyataan untuk masing-masing responden (kelompok tani) maka diperoleh total skor 405 dengan letak indeks ditentukan berdasarkan skala likert berikut:

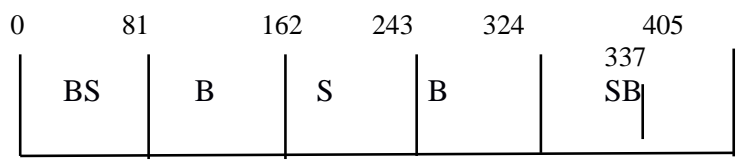

Secara presentase, angka indeks komunikasi penyuluhan PPL 4 dalam teknologi usahatani terletak pada :

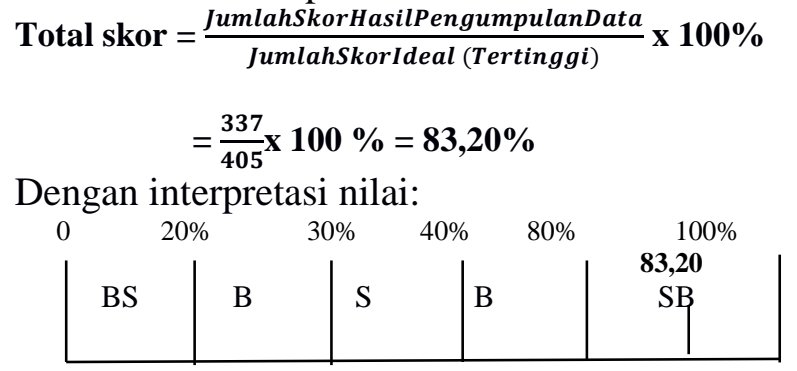

Berdasarkan hasil analisis menggunakkan skala likert, maka dapat diketahui bahwa peran komunikasi penyuluhan dari PPL 4 dalam teknologi usahatani berada pada titik $83,20 \%$ dan tergolong sangat baik.

\section{KESIMPULAN DAN SARAN}

Kesimpulan

Teknik berkomunikasi diperoleh PPL 1 dengan skor $\mathbf{9 4 , 5 6 \%}$ tergolong sangat baik, PPL 4 mendapat skor $\mathbf{8 3 , 2 0 \%}$ tergolong sangat baik, PPL 2 mendapat skor $\mathbf{8 2 , 9 6 \%}$ tergolong sangat baik dan PPL 3 mendapat skor 71,11\% tergolong baik. Jadi dalam penyuluhan yang dilakukan masing-masing PPL yang ada di Kecamatan Langowan Barat cenderung baik. Penerimaan dan pemahaman kegiatan penyuluhan oleh PPL kepada petani di Kecamatan Langowan Barat yang terdiri atas 16 Desa, hasil penelitian menunjukkan bahwa Penyuluhan yang dilakukan masing-masing PPL yang dinilai oleh petani, dimana rata-rata hasil penyuluhan cenderung baik. Kelompok Tani yang ada di Kecamatan Langowan Barat dapat menerima dan melakukan materi yang telah disampaikan Petugas Penyuluh Lapangan.

\section{Saran}

Peran Komunikasi Petugas Penyuluh Lapangan perlu di pertahankan dan dikembangkan agar usahatani yang ada di Kecamatan Langowan Barat akan terus berkembang. Serta diadakanya fasilitas sebagai alat bantuan saat penyuluhan sehingga dapat membuat penyuluhan menjadi lebih baik. Pertahankan dan kembangkan materi yang telah diterima dari hasil penyuluhan agar penghasilan yang diperoleh dapat bertambah dan menunjang untuk kebutuhan petani.

\section{DAFTAR PUSTAKA}

Anwar, A. (1995). Ilmu Komunikasi; Sebagai Pengantar Ringkas. Jakarta

Effendi, Onong Uchjana.1995. "Filsafat Komunikasi". Bandung.

Hernanto, F., 1996. Ilmu Usaha Tani. Penebar Swadaya. Jakarta

Kelsey, LD and Cannon CH. 2001. Cooperative Extension Work. Comstock Publishing Associates. New York.

Kincaid, D. L., Schramm, W., \& Setiadi, A. (1977). Asas-asas komunikasi antara manusia. Lembaga Penelitian, Pendidikan dan Penerangan Ekonomi dan Sosial Jakarta.

Ludlow, Ron \& Panton, Fergus. Komunikasi Efektif. Penerbit Andi, Yogyakarta.

Madikanto, Totok. 2009. Penyuluhan Pembangunan Pertanian. UNS Press. Surakarta 
Mubyarto, 1995. Pengantar Ekonomi Pertania. Jakarta: LP3ES

Mulyana, Deddy, 2005. Ilmu Komunikasi Suatu Pengantar. Bandung : Remaja Rosdakarya.

Purwanto, Djoko. 2009. Komunikasi Bisnis. Penerbit Erlangga. Jakarta

Samsudin, U. 1977. Dasar-dasar Penyuluhan dan Modernisasi Pertanian. Penerbit Binacipta. Bandung

Soekartawi. 1988. Prinsip Dasar Komunikasi Pertanian. Universitas Indonesia: UI Press. Jakarta

Suhardiyono, L. 2001. Penyuluhan: Petunjuk Bagi Penyuluhan Pertanian. Erlangga Jakarta.
Suprapto, T. (2009). Pengantar Teori \& Manajemen Komunikasi. Media Pressindo

Van den Ban, A.W. dan H.S. Hawkins. 1999. Penyuluhan Pertanian. Penerbit Kanisius. Yogyakarta.

Widjaja, H.A.W. (2010). Komunikasi , Komunikasi \& Hubungan Masyarakat. Bumi Aksara, Jakarta

Wilbur, Schramm. (1977). Asas-asas Komunikasi Antar Manusia. Jakarta: Grasindo.

Wiriaatmadja, S., 1986. Pokok-pokok Penyuluhan Pertanian, Yasaguna, Jakarta. 